\author{
Карина Авагјан \\ Универзитет у Београду, Филолошки фракултет
}

\begin{abstract}
редмет овог чланка представља анализа литературе која се односи на војни професионални језик. У раду су описана релевантна дела српских, руских и енглеских аутора из ове области. Истраживање је показало да су доминантна поља филолошких интересовања: војна терминологија, професионална и не стандардна лексика (жаргонизми), као и стилска обележја језика војне струке, док је другим језичким слојевима посвећено видно мање пажње.
\end{abstract}

Кључне речи: војна лексика, војска, војни жаргон, стереотип, српски језик, руски језик, енглески језик

\title{
Кратки историјски осврт
}

Eнгеско говорно подручје. Међу првима ко је говорио о војном језику био

Eje Ф. Гроуз у свом „Речнику вулгарног језика” из 1785. године. Анализирајући разговорни језик свог времена, Гроуз се дотиче и језика војника. Сличан, али много детаљнији и потпунији осврт на снижени ниво војне лексике налазимо и у монографији Е. Пертриџа под називом „Slang Today and Yesterday”. Винборт и Флекслер дају још један опширнији приказ стања лексичког састава језика војне струке у коауторском речнику „Dictionary of American Slang”. Као и у претходна два извора, тај речник се бави уопштеним проблемима у стилски обојеној лексици и њеној употреби, а војна лексика само је делић корпуса тог речника.

Руско говорно подручје. На руском говорном подручју проблемом нестандардне лексике, укључујући и војну, бавили су се многи лингвисти: И. В. Арнољд, С. Г. Воркачев, И. Р. Гаљперин, В. С. Јелистратов, Л. П. Крисин, А. А. Леонтјева, А. И. Смирницки, В. А. Хомјаков, А. Д. Швејцер и др. Посебно треба истаћи руског научника В. П. Коровушкина, који је дао значајан допринос истраживању појаве жаргона у руском језику у совјетској војсци. Упоредном лексиком војног жаргона у руском и енглеском језику бавио се Г. А. Судзиловски.

Српско говорно подручје. Од српских аутора војним језиком бавили су се $\mathrm{Pa}-$ томир Животић, Божидар Јововић и Душан Исаковић. 


\section{Преглед одабране литературе}

\section{Захарчук, О. А. (2007), Универсальные характеристики и национально- культурная специфика военного жаргона ${ }^{1}$}

Предмет ове дисертације јесте жаргон у војничкој професији. Полазећи од ова два светска језика, Оксана Захарчук покушава да реши два основна опште лингвистичка задатка: 1) налажење национално специфичних особености војног језика као одраз одговарајућих различитих друштвено-историјских околности фрормирања два народа и њихових језика и војски и 2) налажење општег у војном језику и одговарајућих универзалија, општих језичких својстава људи који се баве истим послом.

Конкретан предмет истраживања ауторке јесте војни жаргон руског и енглеског језика. Избор ова два језика условљен је тиме што су припадници та два говорна подручја дуги низ година доживљавали једни друге противницима током хладног рата. Скоро читав један век живели су у дијаметрално различитим и супротстављеним политичким системима. Овакав компаративни метод има за циљ, пре свега, утврђивање утицаја који друштвено-политичке околности имају на развој језика. Главном околношћу настанка разлика у доживљају и односу према војној стварности руских и америчких војника ауторка сматра чињеницу да је америчка војска професионална, а да се руска, у основи, попуњава регрутима. Овом чињеницом аутор објашњава и констатацију да лексика америчке војске има све одлике професионалног аргоа, док се руски војни жаргон заснива на разговорном језику, односно језику цивила, из чијих редова и потичу руски војници.

На основу тога могло би се претпоставити да су руски војни жаргонизми бројнији и разноврснији од енглеских, али ауторка то у свом раду није доказала. Наиме, имајући у виду да је основни метод који користи компаративан, примери које наводи Оксана Захарчук на једном од два језика увек имају еквиваленте и у другом језику.

Што се другог циља тиче - утврђивања заједничких особина руског и енглеског војног жаргона, ауторка користи следеће методе: лингвокултуролошку анализу, методу компонентне анализе на основу речничких чланака и компаративну методу. Научни допринос овог истраживања огледа се у томе што се по први пут доследно анализира војни жаргон са лингвокултуролошког аспекта, као и уочене и анализиране екстра лингвистичке околности настанка, развоја и опстанка војног жаргона. Скренута је пажња на појаву универзалија и национално-културолошких особина у војном жаргону. Теоретски допринос овог истраживања огледа се у томе да се војни жаргон разматра са становишта лингвокултурологије. У поглављу под насловом „Војни жаргон као врста мета језика” Оксана Захарчук посвећује пажњу теоријском истраживању њених претходника, с тенденцијом истицања идеје универзалија у војном жаргону.

У свом раду ауторка долази и до интересантних запажања везаних за еволуцију војног жаргона. Примећује да се лексички фонд војног жаргона најактивније попуњава у ратним временима, при чему различити ратови диктирају и различити лек-

\footnotetext{
${ }^{1}$ „Универзалне карактеристике и национално-културолошка специфика војног жаргона”.
} 
сички састав одређеног доба. Тај састав понекад опстаје и у мирно доба, али има и трансформациону моћ, што значи да одређена реч може да мења семантику или да постане полисемична. ${ }^{2}$

Реалије које су типичне за одређену нацију и њен историјски ток најбоље се, по мишљењу ауторке, одражавају у ономастици: топонимима, антропонимима и етнонимима - реалијама које немају идентични еквивалент у другом језику, из простог разлога што савезници и противници за два народа често нису исти. Тако за Американце „Али Баба” представља азијског терористу, непријатеља број 1, док за Русе „Али Баба и сорок разбойников” има позитивну конотацију и значи - командант дивизије.

Као корпус за дату дисертацију послужили су најразличитији извори, као на пример речнички чланци војног сленга, савремена књижевна дела, новински чланци, као и разговори са војним лицима. Обим прикупљеног материјала за потребе њеног рада износи око 3.000 војних жаргонизама у периоду од XIX до XXI века.

Ова дисертација је веома интересантна и с лингвокултуролошког аспекта, јер објашњава не само однос војника према језику већ и њихов однос према непријатељу, животу, смрти, миру, рату итд. Корисна је не само за сврхе које је предвидела ауторка, већ и за учење фразеолошких идиома у руском и енглеском језику.

\section{Венедиктова, Л. Н. (2004), Концепт «Война» в языковой картине мира. Сопоставительное исследование на материале английского и русского языков ${ }^{3}$}

Овај рад бави се лингвокултуролошким компаративним истраживањем концепта „рат” у језичкој слици света на материјалу руског и енглеског језика. Језик, каже ауторка, представља одраз стварности која окружује човека и његов однос према тој стварности. Њено лингвокултуролошко истраживање показало је да концепт „рат” има значајно место, како у руској језичкој свести, тако и код говорника енглеског језика. Природно, рат као екстремна појава, тешко схватљива људском уму, била је одувек предмет размишљања многих мислилаца из области филозофије, социологије, политикологије, историје, али на пољу лингвистике ова проблематика остајала је натакнута, иако „рат” као језичка јединица има безброј лексичких израза и језичког материјала везаних за њих, како у руском, тако и у енглеском језику.

На основу материјала ексцерпираног из дескриптивних речника, речника фразеологизама, речника синонима, пословица и изрека, као из сентенција славних личности, новинских чланака („Известия”, „Независимая газета”, „Washington Post”, "Christian Science Monitor", „The Times”, "The Financial Times”, „Moscow News”),

\footnotetext{
${ }^{2}$ Као пример може послужити жаргонизам с антропонимом John. Овај израз је у америчкој војсци првобитно означавао „јавни мушки тоалет”, да би касније, током Другог светског рата, означавао „регрута” (наиме у анкети за регруте као пример се наводило име „John Doe”). Након Другог светског рата пак (1950-1960) „John” још једном мења значење у „поручник”. Данас се овај жаргонизам користи у америчкој полицији, али и у широј јавности, као назив за „неидентификовани леш”. Интересатно је да је на основу овог израза формиран и одговарајући жаргонизам као назив за женски неидентификовани леш - Jane Doe.

3 „Концепт 'рат' у језичкој слици света на материјалу енглеског и руског језика”.
} 
ауторка је одабрала по 300 примера из оба језика, које је затим организовала у лексичке, фразеолошке, паремиолошке јединице и метафоричне моделе.

Венедиктова је настојала да дефинише термин „културолошки концепт”, „стереотип” и „језичка личност” да дефинише суштину концепта „рат” уз помоћ компаративне, интерпретативне, контекстуалне анализе.

Научни новитет рада јесте грађа модела фрејмова лингвокултуролошког концепта „рат” у језичкој слици руског и енглеског језика и у комплетном упоредном опису метафорских модела анализираног концепта.

Научница дефинише терминолошки апарат и састав у који улазе „језичка слика света”, „стереотип”, „језичка личност”, полазећи од дефиниције Л. Вајсгербера, који је под језичком сликом света подразумевао систем духовног и језичког садржаја који одређује посебност културе и менталитета једне језичке заједнице, при чему је језичка слика променљива и подлеже развоју као и сваки живи организам. Ауторка се осврће на многобројне стране и руске научнике који су се бавили том проблематиком, почев од Винштејна, Апресјана, Вежбицке, Арутјунова и др., и обједињује њихова мишљења у комплетан приступ, при чему разграничава „концепт” од „појма” где под „концептом” подразумева „јединицу колективне свести”, а под „појмом” „апстрактну представу".

Ауторка спроводи конкретну концептуалну анализу концепта „рат” у руском и енглеском језику, успоставља везу са другим концептима и истиче етнолингвистички значај у стварању колективне слике везане за „рат” код оба народа. Ауторка каже да је тема конфлликата и ратова одувек заузимала веома важно место у историји човечанства, па чак и саму историју цивилизације назива историјом ратова.

Анализирани концепт реализује се у језику уз помоћ различитих средстава и заузима важно место у језичкој слици света, у којој постоје бинарне опозиције изражене лексемама : «war - peace» / «война - мир», «evil - good» / «зло - добро», «death - life» / «смерть - жизнь». Она набраја многе примере уз детаљну концептуалну анализу у оба језика, а који се односе на лексеме изражене различитим врстама речи, синтагме, идиоме и сл. На крају рада долази до закључка да је у руском језику концепт „рат” реализован већим бројем јединица него у енглеском језику, што објашњава тиме да у историји Русије сваку генерацију обележи неки од ратова, а самим тим је и лексичко гнездо везано за рат вишеграно и дубоко уткано у менталитет руског народа. То, пак, наводи на закључак да концепт „рат” припада културолошки значајним концептима за руски народ. Истраживање је показало да се фразеолошка семантика рата у енглеском и руском језику конкретизује у истом правцу као и код лексике. Ауторка распоређује примере према метафоричким моделима позитивно-негативно: лов, позориште, економска операција, такмичење, флора, фрауна, игра, надметање и др.

Упоредном анализом установљени су доминантни модели универзалног карактера. Корпус универзалних метафроричких модела сличан је у оба језика. На нивоу структуре фрејмова уочава се највећа разлика, што је, по мишљењу ауторке, последица различитости националне свести и различитости језика.

На крају ауторка закључује да њено истраживање није обухватило целокупан садржај постављеног проблема већ отвара перспективу за даље истраживање културолошког концепта „рат”. 


\section{Степина, Т. А. (2005), Психологические и лингвистические аспекты стереотипов русского воинского общения ${ }^{4}$}

Другачијим проблемом - стереотипима у војној комуникацији, бавила се руска ауторка Татјана Степина. Материјал за истраживање Степина је ексцерпирала из оригиналних текстова правилника/устава руске, односно совјетске војске у периоду од XVII до XX века. На овим материјалима Степина је саставила корпус од 1570 језичких јединица, које је истражила у погледу фонетских, лексичко-семантичких, морфолошких и синтаксичких средстава. Сва средства реализују се у стереотипима војне комуникације. Она поставља хипотезу да се у савременој војној заједници стереотипност професионалне комуникације развија и шири, стварајући разлике између језика ове заједнице и језика цивилног друштва. Степина је први аутор који се бави стереотипима војног језика на руском говорном подручју, што њеном раду даје велики научни значај.

Степина, као и Оксана Захарчук, дотиче питање еволуције војног језика, и настоји да одреди место и настанак уставних стереотипа у војном метајезику, развој њихових фонетских, морфолошких, лексичких и синтаксичких промена. Кроз дијахрони приступ анализираном материјалу, који обухвата период од XVII века (први војни устав) до данас, она у периодизацији уставних стереотипа издваја четири етапе, а заснива их на екстра лингвистичким фракторима.

Конкретно, ауторка брани следеће тезе:

1) Будући да стереотипи војне комуникације представљају микро систем јединица војног метајезика они поседују специфику језичке организације која се одражава на свим језичким нивоима (фонетском, морфолошком, лексичко-семантичком и синтаксичком). Та специфика одсликава се у војној професионалној комуникацији кроз концизност, јасноћу, корпоративност и сл.

2) Систем стереотипа има одређене психофизичке, опште лингвистичке и социолошке особине које нису потпуно затворене и подлежу сталним променама.

3) Еволуцијске промене стереотипа руске војне комуникације односе се на све нивое језичке организације и имају тенденције:

а) компресије језичких средстава,

б) стандардизације (унификације) лексичко-семантичке и структурно-синтаксичке моделације,

в) губљења заједничких особина у језичкој организацији војног и цивилног језичког етикета,

г) слабљење језичке реализације социолошког утицаја.

Приликом свог истраживања ауторка примењује разноврсну методологију, али се, пре свега, заснива на опште лингвистичкој субстратној методологији, коју је разрадио проф. А. Гагајев (варијанта системске теорије). Основе ове методологије поставио је проф. Пузирев, чија је основа научног мишљења садржана у „тетрахотомији" - мишљење, језик-реч, комуникација.

\footnotetext{
4 "Психолошки и лингвистички аспекти стереотипа у руској војној комуникацији".
} 


\section{Т. А. Белякова, С. В. Лазаревич (2003), Тематические группы военного жаргона на материале русского и английского языков ${ }^{5}$}

Главна тема овог чланка представља основне особине војног жаргона, које произилазе из његове професионалне оријентације. Основну јединицу анализе у овом раду представљају тематске групе (ТГ), које се проучавају на материјалу руског и енглеског језика. Аутори истичу велику сличност жаргонизама у овим језицима, што говори о заједничком поимању реалија војног живота. Анализом тематских група установљено је да речи из оквира тематске групе припадају сличној типској ситуацији у оквиру исте теме. Аутори чланка сматрају да примарна контрастивна црта тематских група јесте ван језичка условљеност односа међу њеним елементима. За разлику од семантичког поља, које се испољава у мноштву језичких јединица, тематска група се одражава у скупу материјалних или идејних денотата, који су изражени језичким јединицама. Друга важна особина тематских група јесте разно типски однос међу њеним члановима, уколико такав однос уопште постоји. Форма уређивања денотата тематских група јесте навођење, односно набрајање. С обзиром на то да су војна лица, на неки начин, изолована од друштва, да живе у касарнама, хране се у војним мензама, носе униформе, рукују оружјем, много је тематских група специфичних за такву врсту професије.

Специфичне тематске групе везане за војни живот су:

1) одећа (делови униформе и сл.);

2) војна техника;

3) родови војске;

4) живот у касарни;

5) међуљудски односи.

Анализа је показала да се у свим издвојеним тематским групама огледа велика подударност, што је доказ да заједничка црта лексичког система војног жаргона јесте професионална оријентација.

\section{В. П. Коровушкин (2000), Словарь русского военного жаргона}

Овај речник руског војног жаргона обухвата не стандардну лексику и фразеологизме оружаних снага и војних организација Руске империје, СССР-а и Руске Федерације у периоду од XVIII до XX века. Речник садржи 8.000. јединица које се односе на све врсте оружаних снага: пешадију, морнарицу, ПВО, Генералштаб, војне академије и школе, пограничне јединице, државну безбедност, милицију и судство.

Овај речник је први покушај у Русији и у свету сакупљања лексикографског корпуса не стандардне лексике и фразеологије војне вештине по азбучном реду. Јединственост материјала, као и то да није постојало слично штиво, утицали су на субјективност аутора у одабиру и дефиницији одређених јединица, али то, свакако, не умањује значај овог дела. Аутор је био мотивисан променама у развоју војног језика, које су настале као производ сталних ратова у различитим тачкама света. Многобројни учесници тих ратова - професионални официри, као и војници на одслужењу војног рока, за време и после службе уносили су војничку лексику у свој лични фронд речи. При томе се лексика разликује у зависности од земље у којој су

\footnotetext{
5 „Тематске групе војног жаргона руског и енглеског језика”.

6 „Речник руског војног жаргона”.
} 
се ратови водили. Тако је, на пример, у Шпанији за покојника постојао израз „хладно предјело”, а за покојника у Авганистану - „терет”. У Анголи су руски војници виски „Johny Walker” називали „Гуляй, Вася” (Шетај, Васо!) Снајперисти женског пола погрдно су називани „сука-кукушка” (кучка-кукавица), а снајпериста непријатељске стране „барсук” (ракун) (порекло из Босне). Као градиво за израду речника послужила су и књижевна дела Богомолова, Солженицина, Бабеља и многих других руских књижевника, који су у својим делима дочарали лексику „војенштине”.

\section{Б. Јовановић, Р. Животић (1990), Језик и стил ратне вештине}

Код нас се војним језиком бавило мало аутора. Издвајамо Божидара Јововића и др Радомира Животића који су дуги низ деценија објављивали своје чланке везане за језик војне струке или, како они кажу, језик ратне вештине у војном часопису „Војно дело”. Богати материјал су на крају објединили у коауторску монографију под насловом „Језик и стил ратне вештине” из 1990. године.

У овој књизи аутори прилазе језику војне струке као научном језику, обрађујући његов терминолошки систем, форму, стил и сл. Мотив овог истраживања аутори виде у нужности анализе адекватности језичких средстава, који су у употреби војног језика. Аутори полазе од практичних друштвених и научних циљева које систематизују, као утврђивање степена изучености стечених сазнања о употреби језика у војсци, која би се уградила у праксу војних дела. Језик и стил ратне вештине треба да буде прилагођен његовој функцији и да буде у складу са њеним потребама и могућностима.

Као предмет истраживања аутори одређују језик и стил научних и стручних дела, писаних и говорних, из области српске (југословенске) ратне вештине из периода 1960-1987. године. Ту спадају доктринарна дела, уџбеници и приручници, дела војно-политичког карактера, научни и стручни часописи, као и нормативна документа, правила и упутства. Аутори конкретизују свој предмет по следећим целинама:

1) особеност језика и стила југословенске ратне вештине,

2) однос према књижевном језику (правилност),

3) однос према научном језику.

Ради тачног описивања задате теме, аутори врше научну класификацију ратне вештине, утврђују функционални модел и однос између особености, испуњености књижевног изражавања и захтева научности. Врше следеће анализе докумената: аналитичко-синтетичку, компаративну, семантичко-стилистичку, методу фреквенције, статистичку и сл. Анализирају како писани, тако и говорни материјал. Упоредо су разматрани ванјезички елементи: шеме, прегледи, дијаграми итд.

С обзиром на то да је поменута студија синтеза три појединачне монографије два аутора примећујемо извесне неуједначености у примени метода и поступака, као и у језичко-стилском истицању и фрормулисању проблема, његовом критичком преиспитивању и оцењивању.

Размотрићемо први део књиге, у којем се аутори баве особеностима војног језика, његовим основама у примени војне струке. Резултати истраживања, добијени лингвостилистичком анализом и критичким разматрањем језика војне струке с тачке гледишта функционалности навели су језик на његов развојни пут. Дела из ове области (доктринарни документи, стручна периодика, уџбеници и приручници, војна публицистика, научна и стручна дела - говорна и писана, настала на српскохрватском језику, доказују богатство истраживачких могућности и развијен граматички систем, што потврђује да је тим језиком могуће исказати сложене и апстрактне мисли, појмове, поја- 
ве и радње. У даљем тексту сазнајемо да језик и стил војне струке поштује књижевне норме, али има и извесне особености које потичу из војне средине, традиције и карактера војне струке. Наиме, војна средина учинила је свој језик тајновитим и затвореним за отицање података о војним сазнањима. У њему је присутан велики утицај политичког исказа. У суштини, то је једноставан језик, концизан, али с великим бројем устаљених израза (војних идиома) и пун терминолошких јединица, што представља посебан проблем, којем су обојица аутора посветила по једну главу у овој књизи.

Војни језик ратне вештине обилује интернационализмима, који се смењују другим интернационализмима, у зависности од историјског периода и тренутних савезника. Тако су током Другог светског рата и непосредно после њега русизми били јако заступљени, да би касније били нагло истиснути англицизмима. Неколико поглавља ове књиге аутори посвећују абревијатурама, десинишући их као непожељне, јер су у великој мери неадекватне. Поред тога, аутори сматрају да нагомилавање скраћеница потпомаже стварање непотребног и неоправданог „колективног идиолекта”. У вези са тим они предлажу радикалне промене и значајну редукцију, поготово код абревијатура које означавају више појмова, па тиме доприносе конфузији при тумачењу.

У даљем тексту аутори критикују језик и стил српскохрватске ратне вештине, као недовољно научно одређен и изграђен, који обилује непотребним фрразирањем, политички устаљеним фразама и бирократским формама. Предлаже се сарадња с лекторима ради побољшања јасноће изложеног. Када је реч о емоционалном и метафоричком закључује се да у језику ратне вештине та појава скоро да и не постоји, што, по мишљењу аутора, није сасвим исправно, с обзиром на то да сваки текст, па и научни, без метафорских слика остаје сувопаран и једноличан.

На основу граматичке и ортографске анализе аутори долазе до закључка да на примену књижевне норме треба обратити посебну пажњу, поготово у формулисању наслова текстова, чланака и сл. Управо ту се често срећу нелогичности, нејасноће у грађењу синтагми, не конгруенција у оквиру њих, погрешна употреба предлога и слични неправилности - све што не би смело да се догађа, с обзиром на то да они имају изразиту информативну функцију и служе као узор читаоцима.

Још један од проблема присутан у усменом и писаном изражавању војног језика, примећује се у парафразирању, односно „цитатоманији”, при чему се губи не само оригиналност изражавања, већ понекад и сама суштина изреченог.

Може се закључити да метајезик у војној струци, заправо, не постоји, јер сама језичка свест припадника војске није довољно развијена. Постоје само дневни језик, који за научна дела у оквиру војне доктрине није довољан.

Други део књиге односи се на језик командовања, у којем се детаљно даје увод у историју ратовања, где је правовремена команда претпостављеног увек имала велики значај за добијање, односно губитак битке. У свом доста опширном приказу аутори дају многобројне илустративне примере, од старе Кине, па све до Другог светског рата, где су од реторичких способности војсковође зависили животи људи. У савременим условима ратовања долази до појаве командовања притиском на дугме. Материјал за ово истраживање аутори су црпели највише из музејске документације, с обзиром на то да су ратна наређења строго поверљива и нису доступна за јавност.

Приликом овог истраживања биле су употребљене методе квалитативне анализе садржаја, квантитативна мерења у вези с фреквенцијама речи и израза, опширности и степена поимања логичких садржаја команди, након чега је употребљавана метода компарације. 
У првим поглављима овог дела књиге сазнајемо да код самих корисника војне терминологије постоји забуна да ли руковођење и командовање јесу или нису синоними?! Као закључак овог одељка следи претпоставка аутора да је реторика као предмет неопходна у војним институцијама, јер би допринела побољшању и усавршавању основних комуникативних функција, па самим тим и језика командовања. Аутори закључују да код припадника војске треба развијати навику прецизног и тачног изражавања, а то се може постићи кроз уџбенике и отворене дебате и дискусије.

\section{Д. Исаковић (2000), Познавање и употреба нашег и страних језика у Војсци Југославије}

Чланак садржи мишљење и сугестије аутора у вези с употребом стандардног језика и потребом за добрим познавањем и исправном употребом „општег” и „службеног” језика у Војсци Југославије у комуникацији између појединих њених припадника, команди и штабова, при руковођењу и командовању, као и током обуке и других делатности војске. Аутор говори о потреби ангажовања лингвистичких стручњака приликом састављања правила, приручника и упутстава, и сличног материјала. У свом чланку указује на неопходност развијања војне терминологије, сматрајући да постојаћа није сасвим коректна. Незадовољан познавањем матерњег језика припадника Војске Југославије, предлаже методологију усавршавања српског језика за припаднике сталног састава војске.

Поред матерњег језика, аутор истиче и значај страних језика, сматрајући да официри морају познавати стране језике ради праћења војне мисли и технологије кроз страну војну и другу стручну публицистику, и даје сугестије у погледу организације учења и одржавања знања страних језика официра.

\section{Војни лексикон 1981.}

„Војни лексикон”, који је објавио Војноиздавачки завод 1981. године, представља једно од ретких лексикографских издања које обрађује војну тематику и омогућује да се на једноставан и брз начин дође до информација о питањима из војне теорије и праксе. Војни лексикон прецизно дефинише сваки термин који је у употреби у војсци. Тако, на пример, из одредница: „Наређење”, „Наредба”, „Команда”, „Заповест”, „Директива”, „Руковођење”, „Командовање”, „Управљање”, постаје јасно да припадници војне струке морају разграничавати наизглед синонимичне речи, у складу са њиховом речничком дефиницијом. Дефиниције тих речи дате су у складу са стручним поимањем, а наведени су и примери у контексту. Уз речничку јединицу наведени су и синоними, као и страни еквиваленти у француском, енглеском, немачком и руском језику. Код неких речи постоји и етимолошко објашњење или упут од које речи, из ког страног језика је дата реч дошла. Овај лексикон је веома користан за правилну употребу и разумевање војне терминологије, као и упознавање речи из ускопрофесионалног и свакодневног војног живота.

\section{Закључак}

Може се рећи да се војни језик још увек не проучава довољно. Разлози за то су, свакако, објективни. Војска је затворена институција, па материјали који би лингвистима били интересантни за проучавање нису доступни. Зато су се многи аутори, погото- 
во руски, бавили управо оним језичким слојевима који су им били доступни - лексиком и жаргоном. Што се тиче стилистике, стиче се утисак да су једини обрађивани стилови управо они који су ауторима били доступни: стил редова и опште позната војна терминологија. С друге стране, виши стилови, језик официра, званични и разговорни језик, језик војних докумената и сл., вероватно ће још дуго остати скривени од науке.

Српски аутори су доста пажње посветили проблему сужених могућности комуникације војног кадра, која је, свакако, последица крутог војничког устројства, и неадекватне застареле обуке. Такву слику свакако би ваљало изменити, а лингвисти би томе могли допринети. Такође, такво устројство оружаних снага онемогућава и свако социолингвистичко истраживање разних видова комуникације међу војним лицима, као и истраживање утицаја субординације на њихову међусобну комуникацију.

Такође, може се запазити да се војни језик углавном проучава с лексичко-фразеолошке стране, док су синтакса, фонетика и други језички слојеви ретко предмет истраживања. Томе вероватно доприноси чињеница да су дужи војни текстови ретко доступни, и да ниједна војска не би дозволила снимање својих припадника ради евентуалног фонетског, синтаксичког или социолингвистичког истраживања.

\section{Библиографрија}

[1] Белякова Т. А., Лазаревич С. В. (2003.) Тематические группы военного жаргона на материале русского и английского языков, Ученые записки Нижегородской Академии МВД РФ. №5, Н. Новгород.

[2] Бугарски Р. (2010.) Језик и идентитет, Библиотека XX век, Београд.

[3] Бугарски Р. (2006.) Жаргон, Библиотека XX век, Београд.

[4] Бугарски Р. (2006.) Жаргон, Библиотека XX век, Београд.

[5] Венедиктова Людмила Николаевна (2004.) Концепт «Война» в языковой картине мира: сопоставительное исследование на материале русского и английского языков, Тюмень.

[6] Војни лексикон (1981.), Војно издавачки завод, Београд.

[7] Grouz F. (1962.) A Classical Dictionary of the Vulgar Tongue, London

[8] Животић Р., Јововић Б. (1990.) Језик и стил ратне вештине, Центар високих војних школа ОС „Маршал Тито”, Институт за стратегијска истраживања, Београд.

[9] Захарчук О. А. (2007.) Универсальные характеристики и национально-культурная специяика военного жаргона, Челябинск.

[10] Исаковић Д., (2000.) Познавање и употреба нашег и страних језика у војсци Југославије, Часопис „Војно дело” (I), Београд.

[11] Коровушкин, В.П. (2000.) Словарь русского военного жаргона, Издательство Уральского университета, Екатеринбург.

[12] Степина Т. А. (2005.) Психологические и лингвистические аспекты стереотипов русского воинского общения, Пенза.

[13] Степина Т. А. (2004.) Учебное пособие по воинскому речевому этикету, Пенза.

[14] Степина Т. А. (2005.) Языковое отражение эволюции воинской системы субординационных отношений // Диалектика культуры: общество, государство, личность в современной России, Пенза, Изд-во ПГТА, 117-121.

[15] Степина Т. А. (2005.) Морфологическая эволюция воинских команд, Пенза: Изд-во ПАИИ, 68-70. 